\title{
THIRTY-FIFTH ANNUAL LIST OF PAPERS
}

READ BEFORE THE AMERICAN MATHEMATICAL SOCIETY AND SUBSEQUENTLY PUBLISHED, INCLUDING REFERENCES TO THE PLACES OF PUBLICATION

ADAms, C. R. Note on the existence of analytic solutions of non-homogeneous linear $q$-difference equations, ordinary and partial. Read Dec. 30, 1924. Annals of Mathematics, (2), vol. 27, pp. 73-83; Dec., 1925.

- Existence theorems for a linear partial difference equation of the intermediate type. Read Dec. 30, 1924. Transactions of this Society, vol. 28, No. 1, pp. 119-128; Jan., 1926.

Alexander, J. W. Combinatorial analysis situs. Read Feb. 28, 1925. Transactions of this Society, vol. 28, No. 2, pp. 301-329; April, 1926.

Altshiller-Court, N. See Court, N. A.

Ballantine, J. P. On a certain functional condition. Read May 2, 1925. This Bulletin, vol. 32, No. 2, pp. 153-155; March-April, 1926.

Bateman, H. An extension of Lagrange's expansion. Read (San Francisco Section) April 4, 1925. Transactions of this Society, vol. 28, No. 2, pp. 346-356; April, 1926.

BeLl, E. T. An algebra with singular zero. Read (San Francisco Section) Oct. 25, 1924. American Mathematical Monthly, vol. 32, No. 7, pp. 370-375; Aug.-Sept., 1925.

On generalizations of the Bernoullian functions and numbers. Read (San Francisco Section) Oct. 25, 1924. American Journal of Mathematics, vol. 47, No. 4, pp. 277-288; Oct., 1925.

Generalizations of the eight square and similar identities. Read (San Francisco Section) June 19, 1925. Annals of Mathematics, (2), vol. 27, No. 2, pp. 99-104; Dec., 1925.

An algebra of sequences of functions, with an application to the Bernoullian functions. Read Sept. 11, 1925. Transactions of this Society, vol. 28, No. 1, pp. 129-148; Jan., 1926.

On the arithmetical applications of the power series for theta quotients. Read Jan. 1, 1926. Annals of Mathematics, (2), vol. 27, No. 3, pp. 249-257; March, 1926.

Commutative algebraic inversions. Read Jan. 1, 1926. American Mathematical Monthly, vol. 33, No. 4, pp. 206-210; April, 1926.

A ray of numerical functions of $r$ arguments. Read Jan. 1, 1926. This Bulletin, vol. 32, No. 4, pp. 341-345; July-Aug., 1926. 
- On class-number relations implied by representations as sums of an odd number of squares. Read (San Francisco Section) June 12, 1926. Annals of Mathematics, (2), vol. 27, No. 4, pp. 337-348; Sept., 1926.

On a fundamental formula in the theory of class-number relations. Read (San Francisco Section) June 12, 1926. This Bulletin, vol. 32, No. 6, pp. 682-688; Nov.-Dec., 1926.

Bennetr, A. A. Two new arctangent relations for $\pi$. Read Feb. 28, 1925 American Mathematical Monthly, vol. 32, No. 5, pp. 253-255; May, 1925

The four term diophantine arccotangent relation. Read Feb. 28, 1925 Annals of Mathematics, (2), vol. 27, No. 1, pp. 21-24; Sept., 1925

— Incidence and parallelism in biaffine geometry. Read Dec. 30, 1924. Annals of Mathematics, (2), vol. 27, No. 2, pp. 84-86; Dec., 1925. Consecutive quadratic residues. Read Oct. 31, 1925. This Bulletin, vol. 32, No. 3, pp. 283-284; May-June, 1926.

- Large primes have four consecutive quadratic residues. Read Sept. 11, 1925. Tôhoku Mathematical Journal, vol. 27, Nos. 1-2, pp. 52-57; July, 1926.

Bernstein, B. A. Sets of postulates for the logic of propositions. Read (San Francisco Section) June 19, 1925. Transactions of this Society, vol. 28, No. 3, pp. 472-478; July, 1926.

- On the serial relation in Boolean algebras. Read (San Francisco Section) June 12, 1926. This Bulletin, vol. 32, No.5, pp.523-524;Sept.Oct., 1926.

- A general theory of representation of finite operations and relations. Read (San Francisco Section) Oct. 25, 1924. This Bulletin, vol. 32, No. 5, pp. 533-536; Sept.-Oct., 1926.

- On the existence of fields in Boolean algebras. Read (San Francisco Section) April 4, 1925. Transactions of this Society, vol. 28, No. 4, pp. 654-657; Oct., 1926.

Birkhoff, G. D. An extension of Poincare's last geometric theorem. Read Dec. 29, 1920. Acta Mathematica, vol. 47, No. 4, pp. 297-311; 1926.

BLIss, G. A. A boundary value problem in the calculus of variations. Read April 14, 1922. This Bulletin, vol. 32, No. 4, pp. 317-331; July-Aug., 1926.

- A boundary value problem for a system of ordinary linear differential equations of the first order. Read Dec. 30,1924. Transactions of this Society, vol. 28, No. 4, pp. 561-584., Oct., 1926.

Blumberg, $H$. Non-measurable functions connected with certain functional equations. Read (Southwestern Section) Dec. 1, 1917. Annals of Mathematics, (2), vol. 27, No. 3, pp. 199-208; March, 1926. 
Properties of unrestricted real functions. Read (Southwestern Section) Dec. 1, 1923. This Bulletin, vol. 32, No. 2, pp. 132-148; March-April, 1926.

- Note on a theorem of Kempner concerning transcendental numbers. Read April 22, 1916. This Bulletin, vol. 32, No. 4, pp. 351-356; July, 1926.

BORN, M., and WIENER, N. A new formulation of the laws of quantization of periodic and aperiodic phenomena. Read Jan. 2, 1926. Journal of Mathematics and Physics of the Massachusetts Institute of Technology, vol. 5, No. 2, pp. 84-98; Feb., 1926.

Bray, H. E. Green's lemma. Read May 3, 1924. Annals of Mathematics, (2), vol. 26, No. 4, pp. 278-286; June, 1925.

Buchanan, D. Asymptotic satellites near the straight line equilibrium points (elliptical case). Read (San Francisco Section) Dec. 22, 1923. Rendiconti del Circolo Matematico di Palermo, vol. 49, Nos. 2-3, pp. 299-304, 305-342; May-Aug. and Sept.-Dec., 1925.

CAJORI, F. American contributions to mathematical symbolism. Read (San Francisco Section) April 4, 1925. American Mathematical Monthly, vol. 32, No. 8, pp. 414-416; Oct., 1925.

- Early "proofs" of the impossibility of a fourth dimension of space. Read (San Francisco Section) April 3, 1926. Archivio di Storia della Scienza, vol. 7, Nos. 1-2, pp. 25-28; March-June, 1926.

- A notable case of finger reckoning in America. Read (San Francisco Section) Oct. 31, 1925. Isis, vol. 8, No. 2, pp. 325-327; May, 1926.

Ce que Newton doit à Descartes. Read (San Francisco Section) June 19, 1925. L'Enseignement Mathématique, vol. 25, Nos. 1-3, pp. 7-11; Sept., 1926.

CAMP, B. H. Mutually consistent regression surfaces. Read Sept. 10, 1925. Biometrika, vol. 17, Nos. 3-4, pp. 443-458; Dec., 1925.

Campbell, A. D. Plane cubic curves in the Galois fields of order. $2^{n}$. Read Sept. 10, 1925. Annals of Mathematics, (2), vol. 27, No. 4, pp. 395406; Sept., 1926.

CARLson, E. On the convergence of certain methods of closest approximation. Read April 19, 1924. Transactions of this Society, vol. 28, No. 3, pp. 435-447; July, 1926.

On the convergence of trigonometric approximations for a function of two variables. Read April 14, 19.22. This Bulletin, vol. 32, No. 6, pp. 639-641; Nov.-Dec., 1926.

Carman, M. G. Expansion problems in connection with homogeneous linear $q$-difference equations. Read May 1,1926. Transactions of this Society, vol. 28, No. 3, pp. 523-535; July, 1926. 
Carpenter, A. F. Point-line correspondences associated with the general ruled surface. Read (San Francisco Section) April 4 and June 19, 1925. University of Washington Publications in Mathematics, vol. 1, No. 3, pp. 8-28; June, 1926.

Carson, J. R. The Heaviside operational calculus. Read May 2, 1925. This Bulletin, vol. 32, No. 1, pp. 43-68; Jan.-Feb., 1926.

Choquatte, J. See Shohat, J.

Clarke, E. H. On the sum of a definite integral and a function of a point. Read Sept. 7, 1922. Abstract in University of Chicago, Abstracts of Theses, Science Series, vol. 1, pp. 9-15.

Coble, A. B. Double binary forms with the closure property. Read Dec. 29, 1925. Transactions of this Society, vol. 28, No. 3, pp. 357-383; July, 1926.

Colpitts, J. T. Entire functions defined by certain power series. Read (Southwestern Section) Nov. 29, 1924. Annals of Mathematics, (2), vol. 27, No. 3, pp. 209-223; March, 1926.

Court, N. A. (Altshiller-Court, N.). Sur deux cercles sécants. Read Sept. 7, 1923. Mathesis, vol. 39, No. 10, pp. 453-454; Dec., 1925.

- On the de Longchamps circle of the triangle. Read Sept. 8, 1926. American Mathematical Monthly, vol. 33, No. 7, pp. 368-375; Aug.Sept., 1926.

Cowley, E. B. Note on a linear diophantine equation. Read Oct. 28 and Dec. 28, 1922. American Mathematical Monthly, vol. 33, No. 7, pp. 379-381; Aug-Sept., 1926.

Cramlet, C. M. Some general determinant theorems in tensor notation. Read (San Francisco Section) June 19, 1925. Annals of Mathematics, (2), vol. 27, No. 4, pp. 373-380; Sept., 1926.

Crane, R. Another poristic system of triangles. Read April 10, 1925. American Mathematical Monthly, vol. 33, No. 4, pp. 212-214; April, 1926.

DAus, P. H. Certain recursion formulas connected with the solution of $x^{2}+y^{2}=z^{2}$. Read (San Francisco Section) April 4, 1925. American Mathematical Monthly, vol. 32, No. 9, pp. 455-460; Nov., 1925.

DEDERICK, L. S. Successive derivatives of a function of several functions. Read Dec. 29, 1925. Annals of Mathematics, (2), vol. 27, No. 4, pp. 385-394; Sept., 1926.

Dickson, L. E. A new theory of the rational equivalence of linear transformations or pairs of bilinear forms. Read Dec. 26, 1924. Included in the author's Modern Algebraic Theories, Chicago, Sanborn, 1926.

- New division algebras. Read Oct. 31, 1925. Transactions of this Society, vol. 28, No. 2, pp. 207-234; April, 1926. 
All integral solutions of $a x^{2}+b x y+c y^{2}=w_{1} w_{2} \cdots w_{n}$. Read Sept. 9, 1926. This Bulletin, vol.32, No. 6, pp. 644-648; Nov.-Dec., 1926.

Dines, L. L. Definite linear dependence. Read Sept. 11, 1925. Annals of Mathematics, (2), vol. 27, No. 1, pp. 57-64; Sept., 1925.

- On certain symmetric sums of determinants. Read Sept. 11, 1925. American Journal of Mathematics, vol. 47, No. 4, pp. 249-256; Oct., 1925.

Dodd, E. L. The frequency law of a function of several variables with given frequency laws. Read Dec. 26, 1924. Annals of Mathematics, (2), vol. 27, No. 1, pp. 12-20; Sept., 1925.

- The convergence of a general mean of measurements to the true value. Read Feb. 27, 1926. This Bulletin, vol. 32, No. 3, pp. 282-283; May-June, 1926.

Douglas, J. A characteristic property of minimal surfaces. Read Oct. 30, 1926. This Bulletin, vol. 32, No. 6, pp. 635-638; Nov.-Dec., 1926.

- The transversality relative to a surface of $\int F\left(x, y, z, y^{\prime}, z^{\prime}\right) d x$ $=$ minimum. Read Oct. 30, 1926. This Bulletin, vol. 32, No. 6, pp. 669-674; Nov.-Dec., 1926.

DRESDEN, A. Some recent work in the calculus of variations. Read April 2, 1926. This Bulletin, vol. 32, No. 5, pp.475-521; Sept.-Oct., 1926.

DUNKEL, $O$. The alternation of nodes of linearly independent solutions of second order difference equations. Read Dec. 29, 1925. This Bulletin, vol. 32, No. 4, pp. 333-334; July-Aug., 1926.

EISENhART, L. P. Geometries of paths for which the equations of the paths admit $n(n+1) / 2$ independent linear first integrals. Read Feb. 27, 1926. Transactions of this Society, vol. 28, No. 2, pp. 330338; April, 1926.

Емсн, A. On the discriminant of ternary forms and a certain class of surfaces. Read May 1, 1926. Transactions of this Society, vol. 28, No. 3, pp. 432-434; July, 1926.

ETtLINGER, H. J. Note on the continuity of a function defined by a definite Lebesgue integral. Read Oct. 31, 1925. American Mathematical Monthly, vol. 32, No. 10, pp. 510-511; Dec., 1925.

Note on a fundamental lemma concerning the limit of a sum. Read Sept. 11, 1925. This Bulletin, vol. 32, No. 1, pp. 69-71; Jan.-Feb., 1926.

On multiple iterated integrals. Read April 2, 1926. American Journal of Mathematics, vol. 48, No. 3, pp. 215-222; July, 1926.

On the zeros of functions associated with a linear system of the second order. Read Sept. 9, 1926. Proceedings of the National Academy of Sciences, vol. 12, No. 9, pp. 540-544; Sept., 1926. 
Feinler, F. J. A new method for calculating the Bernoulli numbers. Read (San Francisco Section) Dec. 22, 1923. Messenger of Mathematics, vol. 55, No. 3, pp. 40-44; July, 1925.

FIELDS, J. C. The algebraic numbers and division. Read Dec. 30, 1925. Science, new ser., vol. 63, No. 1640, pp. 553-558; June 4, 1926.

Fort, T. The Sturm and Fourier-Budan theorems and mixed differentialdifference equations. Read Jan. 1, 1926. American Mathematical Monthly, vol. 33, No. 4, pp. 194-198; April, 1926.

FrankLIN, P. The elementary theory of almost periodic functions of two variables. Read Oct. 31, 1925. Journal of Mathematics and Physics of the Massachusetts Institute of Technology, vol. 5, No. 1, pp. 40-54; Dec., 1925.

- Functions of a complex variable with assigned derivatives at an infinite number of points and an analogue of Mittag-Leffler's theorem. Read May 2, 1925. Acta Mathematica, vol. 47, No. 4, pp. 371-385; 1926.

- The elementary character of certain multiple integrals connected with figures bounded by planes and spheres. Read Oct. 31, 1925. American Mathematical Monthly, vol. 33, No. 5, pp. 252-261; May, 1926.

The fundamental theorem of almost periodic functions of two variables. Read Feb. 27, 1926. Journal of Mathematics and Physics of the Massachusetts Institute of Technology, vol. 5, No. 4, pp. 201-237; June, 1926.

- Osculating curves and surfaces. Read Feb. 28, 1925. Transactions of this Society, vol. 28, No. 3, pp. 400-416; July, 1926.

FRANKLIN, P., and WiENER, N. Analytic approximations to topological transformations. Read May 2, 1925. Transactions of this Society, vol. 28, No. 4, pp. 762-785; Oct., 1926.

FRINK, O. The operations of boolean algebras. Read May 2, 1925. Annals of Mathematics, (2), vol. 27, No. 4, pp. 477-490; Sept., 1926.

- A proof of Petersen's theorem. Read Feb. 27, 1926. Annals of Mathematics, (2), vol. 27, No. 4, pp. 491-493; Sept., 1926.

Garabedian, C. A. Solution du problème de la plaque rectangulaire épaisse ayant deux côtés appuyés et deux côtés libres, et portant une charge uniformément répartie ou concentrée en son centre. Read Sept. 10, 1925. Abstract in Comptes Rendus de l'Académie des Sciences, vol. 181, No. 9, pp. 319-321; Aug. 31, 1925.

Disque d'épaisseur constante ou variable en rotation uniforme ou accélérée. Read Sept. 9, 1926. Abstract in Comptes Rendus de l'Académie des Sciences, vol. 183, No. 7, pp. 416-418; Aug. 17, 1926. 
Gehman, H. M. Concerning the subsets of a plane continuous curve. Read April 19, Oct. 25, and Dec. 30, 1924. Annals of Mathematics, (2), vol. 27, No. 1, pp. 29-46; Sept., 1925.

On irredundant sets of postulates. Read Oct. 31, 1925. This Bulletin, vol. 32, No. 2, pp. 159-161; March-April, 1926.

- On extending a continuous (1-1) correspondence of two plane continuous curves to a correspondence of their planes. Read May 3, 1924, and Feb. 28, 1925. Transactions of this Society, vol. 28, No. 2, pp. 252-265; April, 1926.

Some conditions under which a continuum is a continuous curve. Read Feb. 27, 1926. Annals of Mathematics, (2), vol. 27, No. 4, pp. 381-384 ; Sept., 1926.

Concerning irreducibly connected sets and irreducible continua. Read Sept. 9, 1926. Proceedings of the National Academy of Sciences, vol. 12, No. 9, pp. 544-547; Sept., 1926.

GLENN, O. E. The invariant system of two associated bilinear connexes. Read May 2, 1925. American Journal of Mathematics, vol. 48, No. 1, pp. 45-56; Jan., 1926.

Graustein, W. C. Semi-parallel maps of surfaces. Read Dec. 29, 1924. Annals of Mathematics, (2), vol. 27, No. 3, pp. 271-278; March, 1926.

- An invariant of a general transformation of surfaces. Read Dec. 29, 1924. This Bulletin, vol. 32, No. 4, pp. 357-364; July-Aug., 1926.

Graves, L. M. Some problems concerning measurable functions. Read April 3, 1926. This Bulletin, vol. 32, No. 5, pp. 529-533; Sept.-Oct., 1926.

Gronwall, T. H. Reflection of radiation from a finite number of equallyspaced parallel planes. Read Feb. 25, 1922. Physical Review, (2), vol. 27, No. 3, pp. 277-285; March, 1926.

- On the zeros of the function $\beta(z)$ associated with the gamma function. Read Sept. 5, 1916. Transactions of this Society, vol. 28, No. 3, pp. 391-399; July, 1926.

Gron wall, T. H., and LaMer, V. K. On the extension of the DebyeHückel theory of strong electrolytes to concentrated solutions. Read May 1, 1926. Science, new ser., vol. 64, No. 1648, p. 122; July 30, 1926.

Grove, V. G. A theory of a general net on a surface. Read Dec. 26, 1924. Transactions of this Society, vol. 28, No. 3, pp. 491-501; July, 1926.

HANCOCK, H. Trigonometric realms of rationality. Read Dec. 28, 1923. Rendiconti del Circolo Matematico di Palermo, vol. 49, No. 2, pp. 263276; May-Aug., 1925.

Hathaway, A. S. Anharmonic groups. Read Dec. 22, 1916. Annals of Mathematics, (2), vol. 27, No. 4, pp. 357-372; Sept., 1926. 
Hildebrandt, T. H. The Borel theorem and its generalizations. Read Dec. 30, 1925. This Bulletin, vol. 32, No. 5, pp. 423-474; Sept.-Oct., 1926.

Hille, E. Some remarks on Dirichlet's series. Read Feb. 28, 1925. Proceedings of the London Mathematical Society, (2), vol. 25, No. 3, pp. 177-184; June, 1926.

- A class of reciprocal functions. Read Sept.11,1925, and Feb. 27, 1926. Annals of Mathematics, (2), vol. 27, No. 4, pp. 427-464; Sept., 1926.

Hollcroft, T. R. Conditions for self dual curves. Read May 2, 1925. Annals of Mathematics, (2), vol. 27, No. 3, pp. 258-270; March, 1926.

Self dual space curves. Read Feb. 27, 1926. American Journal of Mathematics, vol. 48, No. 2, pp. 113-124; April, 1926.

- Harmonic cubics. Read May 1, 1926. Annals of Mathematics, (2), vol. 27, No. 4, pp. 568-576; Sept., 1926.

Hotelling, H. A general mathematical theory of depreciation. Read Dec. 26, 1924, and (San Francisco Section) April 4, 1925. Journal of the American Statistical Association, vol. 20, No. 151, pp. 340353; Sept., 1925.

- Multiple-sheeted spaces and manifolds of states of motion. Read (San Francisco Section) April 4 and Oct. 31, 1925. Transactions of this Society, vol. 28, No. 3, pp. 479-490; July, 1926.

Huntington, E. V. Postulates for reversible order on a closed line (separation of point pairs). Read April 11, 1925. Proceedings of the National Academy of Sciences, vol. 11, No. 11, pp. 687-689; Nov., 1925.

Hurwitz, W. A. A trivial Tauberian theorem. Read Dec. 30, 1924. This Bulletin, vol. 32, No. 1, pp. 77-82; Jan.-Feb., 1926.

INGOLD, L. The geometry of a set of $n$ functions. Read Feb. 28 and April 11, 1925. Annals of Mathematics, (2), vol. 27, No. 4, pp. 494-510; Sept., 1926.

INGRAHAM, M. H. Solution of certain functional equations relative to a general linear set. Read April 11, 1925. Transactions of this Society, vol. 28, No. 2, pp. 287-300; April, 1926.

J ACKson, D. Note on the convergence of Fourier series. Read Oct. 31, 1925. American Mathematical Monthly, vol. 33, No. 1, pp. 39-40; Jan., 1926.

Note on a problem in approximation with auxiliary conditions. Read April 3, 1926. This Bulletin, vol.32, No. 3, pp. 259-262; May-June, 1926.

- Some convergence proofs in the vector analysis of function space. Read Oct. 25, 1924, April 11, 1925, and Dec. 29, 1925. Annals of Mathematics, (2), vol. 27, No.4, pp. 551-567; Sept., 1926. 
On a tensor of the second rank in function space. Read Sept. 9, 1926. This Bulletin, vol. 32, No. 6, pp. 641-643; Nov.-Dec., 1926.

JaMEs, G. On the solution of higher degree algebraic equations. Read (San Francisco Section) April 4, 1925. This Bulletin, vol. 32, No. 2, pp. 162-165; March-April, 1926.

JEFFERY, R. L. Functions of two variables for which the double integral does not exist. Read Feb. 28, 1925. American Mathematical Monthly, vol. 33, No. 3, pp. 142-143; March, 1926.

JenkINs, W. A. On a central difference summation formula. Read April 11, 1925. American Mathematical Monthly, vol. 32, No. 8, pp. 398403; Oct., 1925.

Johnston, C. I. Isosceles-triangle solutions when the two finite bodies are oblate spheroids. Read (San Francisco Section) June 12, 1926. Transactions of the Royal Society of Canada, (3), vol. 20, Section III, pp. $259-274 ; 1926$.

KARPINSKI, L. C. Generalization of a theorem of Nicomachus. Read Jan. 1, 1926. Pp. 289-290 of Nicomachus of Gerasa, Introduction to Arithmetic, translated by M. L. D'Ooge with Notes on Greek Arithmetic by F. E. Robbins and L. C. Karpinski. New York, Macmillan, 1926.

KellogG, O. D. On the classical Dirichlet problem for general domains. Read May 1, 1926. Proceedings of the National Academy of Sciences, vol. 12, No. 6, pp. 397-406; June, 1926.

- Recent progress with the Dirichlet problem. Read Jan. 2, 1926. This Bulletin, vol. 32, No. 6, pp. 601-625; Nov.-Dec., 1926.

On some theorems of Bôcher concerning isolated singular points of harmonic functions. Read Sept. 9, 1926. This Bulletin, vol. 32, No. 6, pp. 664-668; Nov.-Dec., 1926.

Koopman, B. O. Flow in a Mobius strip. Read Jan. 2, 1926. Annals of Mathematics, (2), vol. 27, No. 4, pp. 424-426; Sept., 1926.

On the extension of a method of Briot and Bouquet for the reduction of singular points. Read Sept.9,1926. This Bulletin, vol. 32, No. 6, pp. 674-678; Nov.-Dec., 1926.

Kormes, M. On the functional equation $f(x+y)=f(x)+f(y)$. Read Oct. 31, 1925. This Bulletin, vol. 32, No. 6, pp. 689-693; Nov.-Dec., 1926.

KRYLOFF, N. Approximate solutions of a system of differential equations of mathematical physics by least squares. Read Dec. 29, 1925. This Bulletin, vol. 32, No. 4, pp. 346-350; July-Aug., 1926.

LaMer, V. K. See Gronwall, T. H.

LANE, E. P. Bundles and pencils of nets on a surface. Read Dec. 26, 1924. Transactions of this Society, vol. 28, No. 1, pp. 149-167; Jan., 1926. 
The correspondence between the tangent plane of a surface and its point of contact. Read April 2, 1926. American Journal of Mathematics, vol. 48, No. 3, pp. 204-214; July, 1926.

Wilczynski's and Fubini's canonical systems of differential equations. Read April 2, 1926. This Bulletin, vol. 32, No. 4, pp. 365-373; July -Aug., 1926.

LANGER, R. E. On the momental constants of a summable function. Read Feb. 28, 1925. Transactions of this Society, vol. 28, No. 1, pp. 168-182; Jan., 1926.

On the theory of integral equations with discontinuous kernels. Read Jan. 1, 1926. Transactions of this Society, vol. 28, No. 4, pp. 585639; Oct., 1926.

LANGer, R. E., and Tamarkin, J. D. A notion of uniform integrability. Read May 1, 1926. This Bulletin, vol. 32, No. 4, pp. 335-337; JulyAug., 1926.

LANGFORD, C. H. On quantifiers for general propositions. Read May 1, 1926. This Bulletin, vol. 32, No. 6, pp. 694-704; Nov.-Dec., 1926.

Latimer, C. G. Arithmetics of generalized quaternion algebras. Read Dec. 29, 1924. American Journal of Mathematics, vol. 48, No. 1, pp. 57-66; Jan., 1926.

LEFSCHETZ, S. Intersections and transformations of complexes and manifolds. Read April 13, 1923, and (Southwestern Section) Dec. 1, 1923. Transactions of this Society, vol. 28, No. 1, pp. 1-49; Jan., 1926.

Lehmer, D. H. On the indeterminate equation $t^{2}-p^{2} D u^{2}=1$. Read (San Francisco Section) June 12,1926. Annals of Mathematics, (2), vol. 27, No. 4, pp. 471-476; Sept., 1926.

- Note on the Mersenne number 2139-1. Read (San Francisco Section) June 12, 1926. This Bulletin, vol. 32, No. 5, p. 522; Sept.Oct., 1926.

Lehmer, D. N. On the construction of factor stencils. Read (San Francisco Section) Oct. 31, 1925. This Bulletin, vol. 32, No. 2, pp. 149150; March-April, 1926.

Levy, H. Symmetric tensors of the second order whose covariant derivatives vanish. Read Feb. 28, 1925. Annals of Mathematics, (2), vol. 27, No. 2, pp. 91-98; Dec., 1925.

Forma canonica dei $d s^{2}$ per i quali si annullano i simboli di Riemann a cinque indici. Read May 1, 1926. Abstract in Rendiconti della Reale Accademia dei Lincei, (6), vol. 3, pp. 65-69; Jan. 17, 1926.

Sopra alcune proprietà degli spazi per i quali si annullano i simboli di Riemann a cinque indice. Read May 1, 1926. Abstract in Rendiconti della Reale Accademia dei Lincei, (6), vol. 3, No. 3, pp. 124-129; Feb. 7, 1926. 
Tensors determined by a hypersurface in Riemann space. Read Feb. 28, 1925. Transactions of this Society, vol. 28, No. 4, pp. 671-694; Oct., 1926.

McDonald, J. H. On a class of polynomials in the theory of Bessel's functions. Read Feb. 24, 1906. Transactions of this Society, vol. 28, No. 3, pp. 384-390; July, 1926.

MACDuffee, C. C. The nullity of a matrix relative to a field. Read April 10, 1925. Annals of Mathematics, (2), vol. 27, No. 2, pp. 133-139; Dec., 1925.

Manning, H. P. Definitions and postulates for relativity. Read Oct. 31, 1925. American Mathematical Monthly, vol. 33, No. 2, pp. 83-89; Feb., 1926.

MARIA, A. J. Functions of plurisegments. Read May 3, 1924. Transactions of this Society, vol. 28, No. 3, pp. 448-471; July, 1926.

Mathews, R. M. Cubic curves and desmic surfaces. Read April 10, 1925. Transactions of this Society, vol. 28, No. 3, pp. 502-522; July, 1926.

Messick, C. A. A new method of determining Bernoulli's numbers. Read Dec. 29, 1925. American Mathematical Monthly, vol. 33, No. 4, pp. 214-217; April, 1926.

Mrchal, A. D. Concerning certain solvable equations with functional derivatives. Read Jan. 1, 1926. Proceedings of the National Academy of Sciences, vol. 12, No. 2, pp. 113-116; Feb., 1926.

Miller, G. A. Imprimitive substitution groups. Read April 10, 1925. American Journal of Mathematics, vol. 47, No. 3, pp. 176-180; July, 1925.

- Multiply transitive substitution groups. Read Sept. 11, 1925. Transactions of this Society, vol. 28, No. 2, pp. 339-345; April, 1926.

Moore, C. L. E. Grassmannian geometry in Riemannian space. Read Sept. 10, 1925. Journal of Mathematics and Physics of the Massachusetts Institute of Technology, vol. 5, No. 4, pp. 191-200; June, 1926.

Moore, R. L. Concerning the relation between separability and the proposition that every uncountable point set has a limit point. Read Sept. 10, 1925. Fundamenta Mathematicae, vol. 8, pp. 189-192; 1926.

Conditions under which one of two given closed linear point sets may be thrown into the other by a continuous transformation of a plane into itself. Read Dec. 29, 1920. American Journal of Mathematics, vol. 48, No. 1, pp. 67-72; Jan., 1926.

Concerning indecomposable continua and continua which contain no subsets that separate the plane. Read Dec. 29, 1925. Proceedings of the National Academy of Sciences, vol. 12, No. 5, pp. 359-363; May, 1926.

Covering theorems. Read Dec. 30, 1924. This Bulletin, vol. 32, No. 3, pp. 275-282; May-June, 1926. 
A connected and regular point set which contains no arc. Read Sept. 7, 1923. This Bulletin, vol. 32, No. 4, pp. 331-332; July-Aug., 1926.

Moore, T. W. Notes on the rational plane cubic curve. Read May 1, 1926. This Bulletin, vol. 32, No. 3, pp. 269-274; May-June, 1926.

Moritz, R. E. On the sum of products of $n$ consecutive integers. Read (San Francisco Section) June 19, 1925. University of Washington Publications in Mathematics, vol. 1, No. 3, pp. 29-49; June, 1926.

Morley, F. On differential inversive geometry. Read May 1, 1926. American Journal of Mathematics, vol. 48, No. 2, pp. 144-146; April, 1926.

MORRIs, F. R. Derivation of annuity formulas without series. Read (San Francisco Section) Oct. 25, 1924. American Mathematical Monthly, vol. 32, No. 8, pp. 416-418; Oct., 1925.

MUllemeister, $H$. Afbeelding van de stralen der ruimte op de lijnenparen van een vlak. Read (San Francisco Section) April 4, 1925. Koninklijke Akademie van Wetenschappen te Amsterdam, Verslag van de gewone vergadering der Afdeeling Natuurkunde, vol. 35, No. 2, pp. 296-300; April, 1926.

MURRAy, F. H. On certain families of orbits with arbitrary masses in the problem of three bodies. Read Sept. 7, 1923. Transactions of this Society, vol. 28, No. 1, pp. 74-108; Jan., 1926.

- On certain families of orbits with arbitrary masses in the problem of three bodies (second paper). Read Dec. 30,1924. Transactions of this Society, vol. 28, No. 1, pp. 109-118; Jan., 1926.

NeIkIRK, L. I. Some finite linear non-associative algebras. Read (San Francisco Section) April 7 and Dec. 22, 1923, and June 12, 1926. University of Washington Publications in Mathematics, vol. 1, No. 3, pp. 50-59; June, 1926.

Nelson, C. A. Note on rational plane cubics. Read Sept. 10, 1925. This Bulletin, vol. 32, No. 1, pp. 71-76; Jan.-Feb., 1926.

NowLAN, F. S. Representation of integers by certain ternary cubic forms. Read Dec. 29, 1925. This Bulletin, vol. 32, No. 4, pp. 374-380; JulyAug., 1926.

Nyswander, J. A. A direct solution of systems of linear differential equations having constant coefficients. Read April 18, 1924. American Journal of Mathematics, vol. 47, No. 4, pp. 257-276; Oct., 1925.

Perkins, F. W. On the oscillation of harmonic functions. Read Dec. 30, 1924. Annals of Mathematics, (2), vol. 27, No. 2, pp. 159-170; Dec., 1925.

Pierce, T. A. An approximation to the least root of a cubic equation with application to the determination of units in pure cubic fields. Read Dec. 29, 1925. This Bulletin, vol. 32, No. 3, pp. 263-268; May-June, 1926. 
Pierpont, J. Some modern views of space. Read Dec. 30, 1925. This Bulletin, vol. 32, No. 3, pp. 225-258; May-June, 1926.

- Note on horospheres. Read May 1, 1926. This Bulletin, vol. 32, No. 5, pp. 525-528; Sept.-Oct., 1926.

Poor, V. S. On the double layer potential. Read Jan. 2, 1926. American Mathematical Monthly, vol. 33, No. 3, pp. 136-139; March, 1926.

RaINICH, G. Y. Third paper on tensor analysis. Read Dec. 29, 1924, and Feb. 28, 1925. American Journal of Mathematics, vol. 47, No. 4, pp. 225-248; Oct., 1925.

- Mass in curved space-time. Read Sept. 10, 1925. Proceedings of the National Academy of Sciences, vol. 12, No. 2, pp. 110-113; Feb., 1926.

- Curved space-time and radiation. Read Feb. 27, 1926. Proceedings of the National Academy of Sciences, vol. 12, No. 4, pp. 244-247; April, 1926.

RAYNoR, G. E. Isolated singular points of harmonic functions. Read Oct. 31, 1925. This Bulletin, vol. 32, No. 5, pp. 537-544; Sept.-Oct., 1926.

RIDER, P. R. The figuratrix in the calculus of variations. Read Dec. 26, 1924. Transactions of this Society, vol. 28, No. 4, pp. 640-653; Oct., 1926.

Rirr, J. F. Sur les fonctions méromorphes qui admettent un theorème d'addition et de multiplication. Read Feb. 27,1926. Abstract in Comptes Rendus de l'Académie des Sciences, vol. 182, No. 3, pp. 201-202; Jan. 18, 1926.

Transcendental transcendancy of certain functions of Poincaré. Read Feb. 28, 1925. Mathematische Annalen, vol. 95, No. 5, pp. 671-682; April, 1926.

Robison, G. M. Divergent double sequences and series. Read Dec. 29, 1920. Transactions of this Society, vol. 28, No. 1, pp. 50-73; Jan., 1926.

Roos, C. F. A mathematical theory of competition. Read May 3, 1924. Americal Journal of Mathematics, vol. 47, No. 3, pp. 163-175; July, 1925.

Sheffer, J. M. Systems of equations in an infinity of unknowns, whose solution involves an arbitrary parameter. Read May 3, 1924. Transactions of this Society, vol. 28, No. 2, pp. 266-286; April, 1926.

Shohat, J. (Choquatte, J.). Sur une formule générale dans la théorie des polynomes de Tchebycheff et ses applications. Read Sept. 11, 1925. Abstract in Comptes Rendus de l'Académie des Sciences, vol. 181, No. 10, pp. 329-331; 1925.

On the asymptotic expressions of certain definite integrals. Read April 19, 1924. Annals of Mathematics, (2), vol. 27, No. 1, pp. 3-11; Sept., 1925. 
Sur quelques applications des polynomes de Tchebycheff à plusieurs variables. Read Sept. 8, 1926. Abstract in Comptes Rendus de l'A. cadêmie des Sciences, vol. 183, No. 8, pp. 442-444; Aug. 23, 1926.

- On the asymptotic expressions for Jacobi and Legendre polynomials derived from finite difference equations. Read Dec. 29, 1925. American Mathematical Monthly, vol. 33, No. 7, pp. 354-361; Aug.-Sept., 1926.

SiERPINSKI, W. Nuclear points in the theory of abstract sets. Read Sept. 9, 1926. This Bulletin, vol. 32, No. 6, pp. 649-653; Nov.-Dec., 1926.

Simmons, H. A. The first and second variations of a double integral for the case of variable limits. Read April 2,1926. Transactions of this Society, vol. 28, No. 2, pp. 235-251; April, 1926.

Sisam, C. H. On curves for which all lines through a fixed point are components of first polars. Read Dec. 29, 1923. Messenger of Mathematics, vol. 53, No. 12, pp. 185-189; April, 1924.

Sм IтH, P. A. Approximation of curves and surfaces by algebraic curves and surfaces. Read Feb. 27, 1926. Annals of Mathematics, (2), vol. 27, No. 3, pp. 224-244; March, 1926.

Stone, M. H. The Borel summability of Fourier series. Read Oct. 31, 1925. American Journal of Mathematics, vol. 48, No. 2, pp. 101-112; April, 1926.

- Developments in Legendre polynomials. Read Jan. 2, 1926. Annals of Mathematics, (2), vol. 27, No. 4, pp. 315-329; Sept., 1926.

- A comparison of the series of Fourier and Birkhoff. Read Dec. 30, 1924. Transactions of this Society, vol. 28, No. 4, pp. 695-761; Oct., 1926.

Stouffer, E. B. A simple derivation of Kronecker's relation among the minors of a symmetric determinant. Read Dec. 29, 1925. Proceedings of the National Academy of Sciences, vol. 12, No. 1, pp. 63-64; Jan., 1926.

TAMARKIN, J. D. On Laplace's integral equations. Read May 1, 1926. Transactions of this Society, vol. 28, No. 3, pp. 417-425; July, 1926.

- On Volterra's integro-functional equation. Read May 1, 1926. Transactions of this Society, vol. 28, No. 3, pp. 426-431; July, 1926. See LANGER, R. E.

TAMARKin, J. D., and Wilder, C. E. Note on the second law of the mean for integrals. Read Sept. 11, 1925. This Bulletin, vol. 32, No. 2, pp. 151-152; March-April, 1926.

Thomas, J. M. On normal coordinates in the geometry of paths. Read Jan. 1, 1926. Proceedings of the National Academy of Sciences, vol. 12, No. 1, pp. 58-63; Jan., 1926.

Asymmetric displacement of a vector. Read May 2, 1925. Transactions of this Society, vol. 28, No. 4, pp. 658-670; Oct., 1926. 
Thomas, T. Y. Announcement of a projective theory of affinely connected manifolds. Read Sept. 10, 1925. Proceedings of the National Academy of Sciences, vol. 11, No. 10 pp., 588-589; Oct., 1925.

On conformal geometry. Read Jan. 2,1926. Proceedings of the National Academy of Sciences, vol. 12, No. 5, pp. 352-359; May, 1926.

VANDIVER, H. S. Note on trinomial congruences and the first case of Fermat's last theorem. Read Dec. 29, 1924. Annals of Mathematics, (2), vol. 27, No. 1, pp. 54-56; Sept., 1925.

A criterion that a cubic equation has an integral root. Read Sept. 11, 1925. American Mathematical Monthly, vol. 33, No. 2, pp. 9496; Feb., 1926.

- Summary of results and proofs concerning Fermat's last theorem. Read Dec. 29, 1924. Proceedings of the National Academy of Sciences, vol. 12, No. 2, pp. 106-109; Feb., 1926.

Transformation of the Kummer criteria in connection with Fermat's last theorem. Read April 27, 1918. Annals of Mathematics, (2), vol. 27, No. 3, pp. 171-176; March, 1926.

- Application of the theory of relative cyclic fields to both cases of Fermat's last theorem. Read Sept. 11, 1925. Transactions of this Society, vol. 28, No. 3, pp. 554-560; July, 1926.

VAN VLECK, E. B. On limits to the absolute values of the roots of a polynomial. Read Dec. 29, 1923. Bulletin de la Sociêté Mathématique de France, vol. 53, Nos. 1-2, pp. 105-125; 1925.

WedDerburn, J. H. M., Note on matrices in a given field. Read May 2, 1925. Annals of Mathematics, (2), vol. 27, No. 3, pp. 245-248; March, 1926.

Whelan, A. M. The theory of the binary octavic. Read Feb. 24, 1923. American Journal of Mathematics, vol. 48, No. 2, pp. 73-100; April, 1926.

Whyburn, G. T. Two-way continuous curves. Read May 1, 1926. This Bulletin, vol. 32, No. 6, pp. 659-663; Nov.-Dec., 1926.

WIENER, N. The representation of functions by trigonometrical integrals. Read Dec. 30, 1924. Mathematische Zeitschrift, vol. 24, No. 3, pp. 575616; Dec., 1925.

Verallgemeinerte trigonometrische Entwicklungen. Read Oct. 25, 1924. Nachrichten von der Gesellschaft der Wissenschaften zu Göttingen, 1925, No. 2, pp. 151-158; 1926.

The operational calculus. Read May 2, 1925. Mathematische Annalen, vol. 95, No. 4, pp. 557-584; Feb., 1926.

The harmonic analysis of irregular motion. Read Oct. 31, 1925. Journal of Mathematics and Physics of the Massachusetts Institute of Technology, vol. 5, No. 2, pp. 99-121; Feb., 1926. 
The harmonic analysis of irregular motion. Second paper. Read Oct. 31, 1925. Journal of Mathematics and Physics of the Massachusetts Institute of Technology, vol. 5, No. 3, pp. 158-189; March, 1926.

See Born, M., FrankLin, P.

Wilder, C. E. See Tamarkin, J. D.

WILDER, R. L. A property which characterizes continuous curves. Read Oct. 31, 1925. Proceedings of the National Academy of Sciences, vol. 11, No. 12, pp. 725-728; Dec., 1925.

A theorem on connected point sets which are connected im kleinen. Read Oct. 31, 1925. This Bulletin, vol. 32, No. 4, pp. 338-340; JulyAug., 1926.

Williams, K. P. Non-synchronized relative invariant integrals. Read April 11, 1925. Transactions of this Society, vol. 28, No. 1, pp. 198-206; Jan., 1926.

Williams, W. L. G. On the formal modular invariants of binary forms. Read Sept. 11, 1925. Journal de Mathématiques Pures et Appliquées, (9), vol. 4, No. 2, pp. 169-192; 1925.

- Fundamental systems of formal modular protomorphs of binary forms. Read Sept. 8, 1922. Transactions of this Society, vol. 28, No. 1, pp. 183-197; Jan., 1926.

WILson, W. A. Some properties of limited continua irreducible between two points. Read Sept. 10, 1925. Transactions of this Society, vol. 28, No. 3, pp. 536-553; July, 1926.

- On the structure of a continuum limited and irreducible between two points. Read Oct. 31, 1925. American Journal of Mathematics, vol. 48, No. 3, pp. 147-168; July, 1926.

Winger, R. M. Self-projective rational septimics. Read (San Francisco Section) April 6, 1918, and Sept. 18, 1923. American Journal of Mathematics, vol. 47, No. 3, pp. 207-223; July, 1925.

- The ternary Hesse group and its invariants. Read (San Francisco Section) June 19, 1925. University of Washington Publications in Mathematics, vol. 1, No. 3, pp. 60-80; June, 1926.

Wong, B. C. On the correspondence between space sextic curves and plane quartics in four-space. Read April 3, 1926. This Bulletin, vol. 32, No. 2, pp. 156-158; March-April, 1926. 